\title{
Metabolism of 5-Methyltetrahydrofolate by Lactobacillus casei
}

\author{
By BARRY SHANE AND E. L. ROBERT STOKSTAD \\ Department of Nutritional Sciences, University of California, \\ Berkeley, California 94720, U.S.A.
}

(Received I8 May I977)

The metabolism of $5-\left[\mathrm{Me}^{14} \mathrm{C}\right]$ methyltetrahydrofolate in Lactobacillus casei proceeded oxidatively with incorporation of label into purine and thymidylate derivatives. No labelled methionine was formed. ( $l$ )-5-Methyltetrahydrofolate, the natural isomer, was not a substrate for the $L$. case $i$ folylpoly- $\gamma$-glutamate synthetase although the unnatural $(d)$-isomer was slowly metabolized to the diglutamate form.

\section{INTRODUCTION}

We have previously shown that pteroylpolyglutamates, once transported, are better growth promoters of Lactobacillus casei than pteroylmonoglutamates (Shane \& Stokstad, 1976). The rate-limiting step in the utilization of pteroylpolyglutamates by this organism is transport into the cell, while intracellular metabolism, and not transport, is rate-limiting with pteroylmonoglutamates. In vitro studies have also shown that pteroylpolyglutamates are often better substrates than the corresponding monoglutamates for folate-requiring enzymes (Burton \& Metzenberg, 1975; Cheng, Shane \& Stokstad, 1975; Coward et al., I974, 1975; Curthoys \& Rabinowitz, I972; Kisliuk, Gaumont \& Baugh, I974; Powers \& Snell, 1976; Salem, Pattison \& Foster, 1972; Whitfield, Steers \& Weissbach, 1970).

To investigate which step in pteroylmonoglutamate metabolism might be rate-limiting, the metabolism of $5-\left[\mathrm{Me}^{14} \mathrm{C}\right]$ methyl- $\mathrm{H}_{4} \mathrm{PteGlu}$ and $5-$ methyl- $_{4}\left[{ }^{3} \mathrm{H}\right] \mathrm{PteGlu}$ (for nomenclature, see Methods) were compared in order to assess the turnover of intracellular folate via various metabolic pathways. Although two mechanisms have been described for 5 -methyl- $\mathrm{H}_{4} \mathrm{PteGlu}$ formation in bacteria involving the reduction of 5 , I O-methylene- $\mathrm{H}_{4} \mathrm{PteGlu}$ or the direct transfer of a methyl group from trimethylsulphonium to $\mathrm{H}_{4} \mathrm{PteGlu}$ (Wagner et al., 1967), the only known route for the metabolism of methyltetrahydrofolates is via methionine synthesis (Taylor \& Weissbach, 1973) but attempts to detect methionine synthetase activity in $L$. casei have proved unsuccessful (Galivan, I97I ; Kisliuk, 1971).

\section{METHODS}

Nomenclature. The abbreviations used are: PteGlu, pteroylglutamic acid, folic acid; PteGlu ${ }_{n}$, pteroylmonoto pteroyloligo- $\gamma$-L-glutamic acid, $n$ indicating the number of glutamic; acid residues; $\mathbf{H}_{4}$ PteGlu $_{n}, 5,6,7,8-$ tetrahydropteroylmono- to 5,6,7,8-tetrahydropteroyloligo- $\gamma$-L-glutamic acid. The symbols $(l)$ and $(d)$ are used to denote the natural and unnatural diastereoisomers of $\mathbf{H}_{4}$ PteGlu ${ }_{n}$, respectively, due to the asymmetric centre at the C-6 position, and do not indicate optical activity.

Materials. $(l)-5-\left[\mathrm{Me}^{-14} \mathrm{C}\right] \mathrm{Methyl}-\mathrm{H}_{4} \mathrm{PteGlu}_{n}(n=1,3,5$ and 7$)$ (specific activity $\left.47 \mathrm{mCi} \mathrm{mmol}^{-1}\right),(d l)-5-$ methyl- $\mathrm{H}_{4}\left[{ }^{3} \mathrm{H}\right] \mathrm{PteGlu}$ (sp. act., $500 \mathrm{mCi} \mathrm{mmol}^{-1}$ ), and folic acid $\gamma$-polyglutamates $\mathrm{PteGlu}_{2-7},\left[{ }^{3} \mathrm{H}\right] \mathrm{PteGlu}{ }_{2-7}$ (sp. act., $4 \mathrm{mCi} \mathrm{mmol}^{-1}$ ), and PteGlu $\left.{ }_{n}-{ }^{14} \mathrm{C}\right] \mathrm{Glu}-\mathrm{Glu}\left(n=0, \mathrm{I}, 2\right.$ and 3) (sp. act., 100 to $500 \mu \mathrm{Ci} \mathrm{mmol}^{-1}$ ) were synthesized and purified as described previously (Shane \& Stokstad, 1976). ( $\mathrm{dl}$ )-5-[Me-14 $\mathrm{C}] \mathrm{Methyl-}$ $\mathrm{H}_{4}$ PteGlu (sp. act., $54 \mathrm{mCi} \mathrm{mmol}^{-1}$ ), L-[Me- $\left.{ }^{14} \mathrm{C}\right]$ methionine (sp. act., $56 \mathrm{mCi} \mathrm{mmol}^{-1}$ ) and $S$-adenosyl-L-

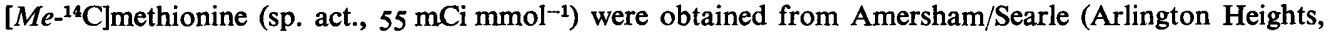
Illinois, U.S.A.); $\left[8{ }^{3} \mathrm{H}\right]$ adenine (sp. act., $14 \mathrm{Ci} \mathrm{mmol}^{-1}$ ), $\left[8-{ }^{3} \mathrm{H}\right]$ guanine (sp. act., $5 \cdot 5 \mathrm{Ci} \mathrm{mmol}^{-1}$ ), $\left[6{ }^{3} \mathrm{H}^{3}\right.$ uracil 
(sp. act., $20 \mathrm{Ci} \mathrm{mmol}^{-1}$ ), $\left[5^{-3} \mathrm{H}\right]$ cytosine (sp. act., $26 \mathrm{Ci} \mathrm{mmol}^{-1}$ ) and $\left[6-{ }^{3} \mathrm{H}\right]$ thymine (sp. act., $7 \cdot \mathrm{I} \mathrm{Ci} \mathrm{mmol}{ }^{-1}$ ) were from Schwarz/Mann (Orangeburg, New Jersey, U.S.A.).

Unlabelled purine and pyrimidine derivatives were obtained from Sigma, DNAase (bovine pancreas; 1500 units $\mathrm{mg}^{-1}$ ) from Worthington, and RNAase (bovine pancreas; 64 units $\mathrm{mg}^{-1}$ ) and RNAase-CB (predominantly $T_{2}$, remainder $T_{1} ; 21$ units $\mathrm{mg}^{-1}$ ) from Calbiochem.

Organism and growth conditions. Lactobacillus casei (ATCC7469) was cultured as described previously (Tamura et al., 1972) with PteGlu (2.3 nM) added to the media.

Uptake and metabolism of folates, purine and pyrimidine bases, and methionine. Bacteria were harvested by centrifuging from growth media in late exponential phase $\left(20\right.$ to $24 \mathrm{~h}$ at $\left.37^{\circ} \mathrm{C}\right)$ and were washed with, and resuspended in $50 \mathrm{~mm}-\mathrm{K}_{2} \mathrm{HPO}_{4} / 100$ mM-sodium acetate, adjusted to $\mathrm{pH} 6$ with $\mathrm{H}_{3} \mathrm{PO}_{4}$, and containing $\mathrm{I} \%(\mathrm{w} / \mathrm{v})$ glucose and $5 \mathrm{mM}$-mercaptoethanol. Transport of labelled bases and methionine was measured as described previously for folates (Shane \& Stokstad, 1975, 1976). Bacterial dry weight was estimated by $E_{640}^{1 \mathrm{~cm}}$.

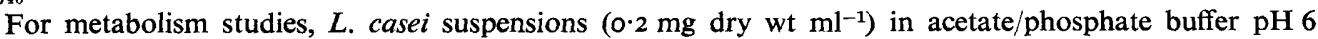
(containing glucose and mercaptoethanol), were preincubated for $15 \mathrm{~min}$ at $37^{\circ} \mathrm{C}$ with labelled methyltetrahydrofolates or methionine, then filtered (HA filters, Millipore Corp., $0.45 \mu \mathrm{m}$ pore size), washed with buffer, resuspended in fresh buffer $\left(0.4 \mathrm{mg}\right.$ dry wt $\left.\mathrm{ml}^{-1}\right)$, and incubated at $37{ }^{\circ} \mathrm{C}$ with shaking. Samples $(5 \mathrm{ml})$ were removed at $0,1,2,5$ and $24 \mathrm{~h}$ and filtered, and the bacteria (plus filter) were resuspended in $\mathrm{O} . \mathrm{I}$ M-potassium phosphate buffer $\mathrm{pH} 7$, containing $0.2 \mathrm{M}$-mercaptoethanol. Intracellular labelled compounds were extracted by boiling for $5 \mathrm{~min}$, and insoluble material was removed by centrifuging and resuspended in water $(5 \mathrm{ml})$. Mercaptoethanol was added to the cell-free medium.

The metabolism of labelled purine and pyrimidine bases was studied in a similar manner except that the bacteria were preincubated with the ${ }^{3} \mathrm{H}$-labelled bases $\left(5 \mu \mathrm{Ci} \mathrm{ml}^{-1}\right)$ for $2 \mathrm{~h}$ before incubating with (l)-5-[Me- $\left.{ }^{14} \mathrm{C}\right]$ methyl- $\mathrm{H}_{4}$ PteGlu $(0.5 \mu \mathrm{M})$ for $15 \mathrm{~min}$. After resuspension and incubation in fresh buffer for $2 \mathrm{~h}$, the bacteria were filtered, washed, and extracted with boiling $0 \cdot \mathrm{I}$ M-potassium phosphate buffer $\mathbf{p H} 7$, containing $0.2 \mathrm{M}$-mercaptoethanol $(2 \mathrm{ml})$. Insoluble material, collected by centrifuging, was washed Io times with $\mathrm{H}_{2} \mathrm{O}(5 \mathrm{ml})$, resuspended in $20 \mathrm{mM}$-acetate buffer $\mathrm{pH} 4.5(\mathrm{I} \mathrm{ml})$, containing RNAase (50 units) and RNAase $\mathrm{T}_{2}$ (15 units), and incubated at $37^{\circ} \mathrm{C}$ for $12 \mathrm{~h}$. The mixtures were heated at $100{ }^{\circ} \mathrm{C}$ for $5 \mathrm{~min}$, cooled, centrifuged and the supernatants (termed the RNAase extracts) were collected. Extracellular extracts, after addition of mercaptoethanol ( $0.2 \mathrm{M})$, were adjusted to $\mathrm{pH} 4$ with acetic acid. Active charcoal $\left(50 \mathrm{mg} \mathrm{ml}^{-1}\right.$ ) was added and the mixtures were stirred for $15 \mathrm{~min}$. The charcoal was then collected by centrifuging, washed twice, "with $\mathrm{H}_{2} \mathrm{O}$, and extracted with $60 \%(\mathrm{v} / \mathrm{v})$ ethanol containing $\mathrm{O} \cdot \mathrm{I} \mathrm{M}-\mathrm{NH}_{4} \mathrm{OH}$ $\left(50 \mathrm{ml} \mathrm{g}^{-1}\right)$. Charcoal was removed by filtration and the ethanol extract was evaporated to dryness under reduced pressure at $40^{\circ} \mathrm{C}$. The residue was dissolved in $0^{\prime}$ I M-potassium phosphate bufier $\mathrm{pH} 7$, containing $0.2 \mathrm{M}$ mercaptoethanol $(2 \mathrm{ml})$.

Portions of the various fractions were added to vials together with a Triton $X-100 /$ toluene $(1: 2, v / v)$ scintillation mixture (Goldmark \& Linn, 1970). Counting efficiencies, determined by external standardization or by a channels ratio method, were about $80 \%$ for ${ }^{14} \mathrm{C}$ and $25 \%$ for ${ }^{3} \mathrm{H}$. In dual labelling experiments, the ${ }^{14} \mathrm{C}$ efficiency was about $35 \%$.

Identification of labelled compounds. Extracts were chromatographed on Sephadex G-25 and DEAEcellulose (DE52, Whatman) before and after folyl- $\gamma$-glutamyl carboxypeptidase (conjugase) treatment as previously described (Buehring, Tamura \& Stokstad, 1974; Shane \& Stokstad, 1975; Tamura et al., 1972). Individual labelled peaks were rechromatographed together with appropriate standards. The chromatographic behaviour of folates on Sephadex G-25 and DEAE-cellulose has been described in detail (Buehring et al., 1974; Shin, Buehring \& Stokstad, $1972 a$; Shin, Williams \& Stokstad, 1972b).

Identification of $3^{\prime}$-ribonucleotides. $3^{\prime}$-Ribonucleotide standards were added to the RNAase extracts and portions were lyophilized to dryness, resuspended in $\mathrm{H}_{2} \mathrm{O}(20 \mu \mathrm{l})$ and applied to cellulose thin-layer plates (Eastman 13255). Ribonucleotides were separated by two-dimensional chromatography using isobutyric acid/o.5 M- $-\mathrm{NH}_{4} \mathrm{OH}(5: 3, \mathrm{v} / \mathrm{v})$ and 2-propanol/6 $\mathrm{M}-\mathrm{HCl}(7: 3, \mathrm{v} / \mathrm{v})$ as solvent systems (Delk \& Rabinowitz, 1975; Nishimura, 1972). Standard compounds were detected by ultraviolet absorption (254 $\mathrm{nm}$ ) and labelled compounds by scintillation autography (Contractor \& Shane, 1969; Klagsbrun, 1973).

Treatment of kinetic data. $K_{m}$ and $V_{\max }$ values were calculated by an unweighted non-linear regression method (Wilkinson, 196I) with six cycles of reiteration (Cleland, 1967). Where appropriate, $V_{\max }$ values are expressed as micromolar increase in intracellular concentration per minute, assuming an intracellular water volume of $4 \mathrm{ml}$ ( $\mathrm{g}$ dry wt bacteria) $)^{-1}$ (Kepes \& Cohen, 1962). 


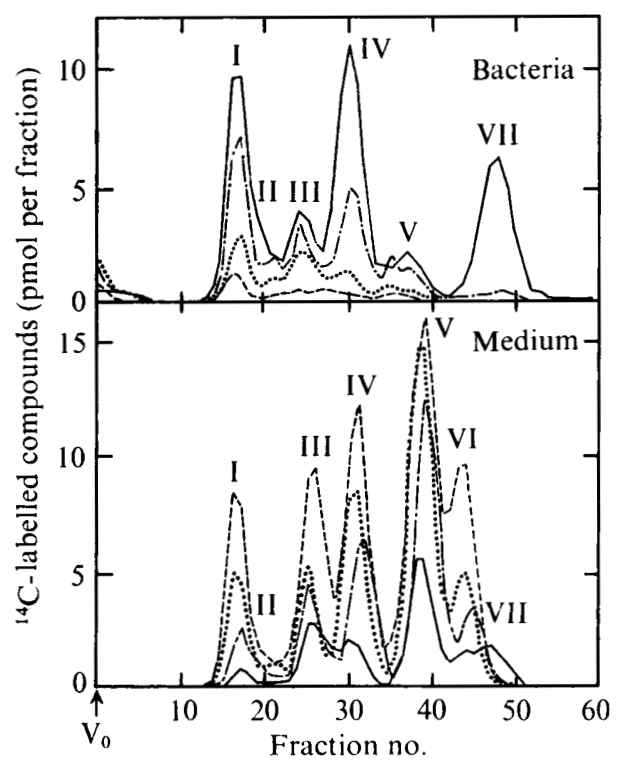

Fig. 1. Metabolism of $(l)-5-\left[\mathrm{Me}^{14} \mathrm{C}\right] \mathrm{methyl}-\mathrm{H}_{4} \mathrm{PteGlu}$ by Lactobacillus casei. Bacteria were preincubated for $15 \mathrm{~min}$ with $(l)-5-\left[\mathrm{Me}^{-14} \mathrm{C}\right]$ methyl-H ${ }_{4}$ PteGlu $\left(0.45 \mu \mathrm{M}\right.$; sp. act., $\left.47 \mathrm{mCi} \mathrm{mmol}^{-1}\right)$ to an intracellular ${ }^{14} \mathrm{C}$-labelled vitamin concentration of $99 \mu \mathrm{M}$, then filtered, washed, and resuspended in fresh buffer and reincubated with shaking, as described in Methods. At I (-), $2(-\cdot-)$, $5(\cdots)$ ) and $24 \mathrm{~h} \mathrm{(--)}$, portions were removed, filtered and extracted with boiling buffer, and intracellular extract (equivalent to $0.8 \mathrm{mg}$ dry wt bacteria) and cell-free medium $(2 \mathrm{ml}$ ) were applied to Sephadex G-25 columns $(200 \times 0.7 \mathrm{~cm})$. The columns were eluted with $0.1 \mathrm{M}$-phosphate buffer pH 7 , containing $0.2 \mathrm{M}$-mercaptoethanol, and fractions $(\mathrm{I} \cdot 7 \mathrm{ml})$ were collected from the void volume $\left(\mathrm{V}_{0}\right)$ as indicated by the elution position of Blue Dextran 2000. The columns were precalibrated with standards whose approximate elution positions were as follows: PteGlu (fraction

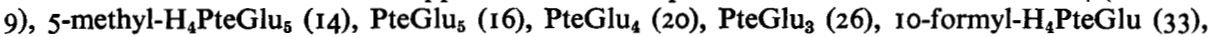
Io-formyl-PteGlu (35), PteGlu 2 (35), 5-methyl-H PteGlu (49), PteGlu (55), dTTP (I6), dTMP (23), ATP (23), methionine (23), formaldehyde (24), formate (24), dT (27), ${ }^{3} \mathrm{H}_{2} \mathrm{O}$ (27), p-aminobenzoylglutamate (28), $S$-adenosylmethionine (3I), AMP (37), adenosine (5I), adenine (64).

\section{RESULTS}

\section{General characteristics of 5-methyl- $\mathrm{H}_{4}$ PteGlu metabolism}

After bacteria had been preincubated with labelled 5-methyl- $\mathrm{H}_{4}$ PteGlu for $15 \mathrm{~min}$, more than $95 \%$ of the intracellular label chromatographed on Sephadex G-25 at the position of 5-methyl- $\mathrm{H}_{4} \mathrm{PteGlu}$. The initial exit rates of radioactive label after resuspending the bacteria in fresh buffer were 0.01 to $0.02 \mathrm{~min}^{-1}$.

The Sephadex G-25 elution profiles obtained with extracts from bacteria incubated with (l)-5-[Me-14 $\mathrm{C}]$ methyl- $\mathrm{H}_{4} \mathrm{PteGlu}$ showed that within $\mathrm{I} \mathrm{h}$ about $90 \%$ of the ${ }^{14} \mathrm{C}$-label had been transferred to four major metabolites (peaks I, III, IV and V, Fig. I) together with some high molecular weight material eluting at the void volume. About $20 \%$ of the label at I h was not extracted from bacteria by boiling buffer. By $2 \mathrm{~h}$, practically no ${ }^{14} \mathrm{C}$-label in the bacteria or medium eluted at the 5 -methyl- $\mathrm{H}_{4}$ PteGlu position (peak VII, Fig. I). Treatment of the intracellular extracts with conjugase did not affect the Sephadex G-25 elution profiles of ${ }^{14} \mathrm{C}$-labelled metabolites, indicating that none of the labelled compounds was a folylpolyglutamate. Also, no labelled metabolites comparable to compounds I to VI were found when bacteria were incubated with 5 -methyl- $\mathrm{H}_{4}\left[{ }^{3} \mathrm{H}\right] \mathrm{PteGlu}$ (Fig. 3), indicating that they were non-folate in nature. This was confirmed by their chromatographic properties on DEAE-cellulose (not shown). With the exception of unmetabolized 5-methyl- $\mathrm{H}_{4} \mathrm{PteGlu}$, none of the labelled compounds chromatographed at the position of 


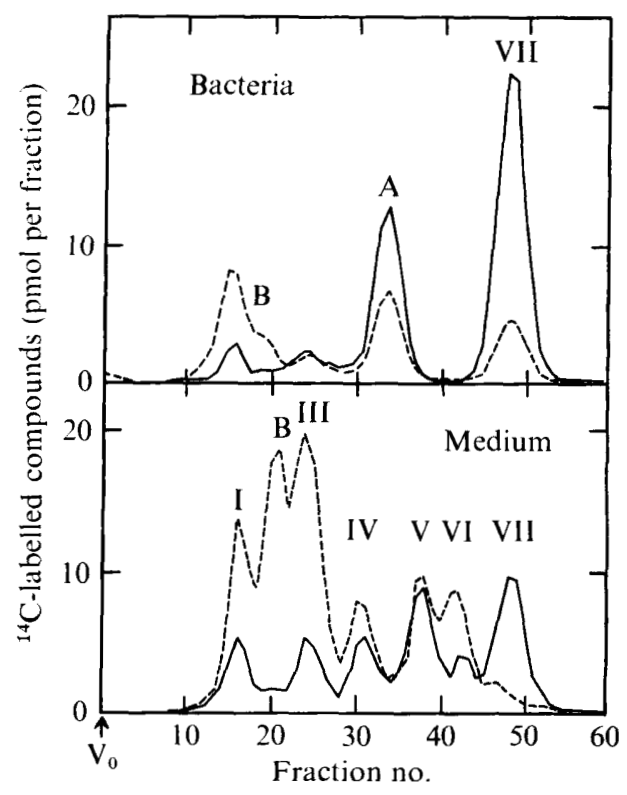

Fig. 2

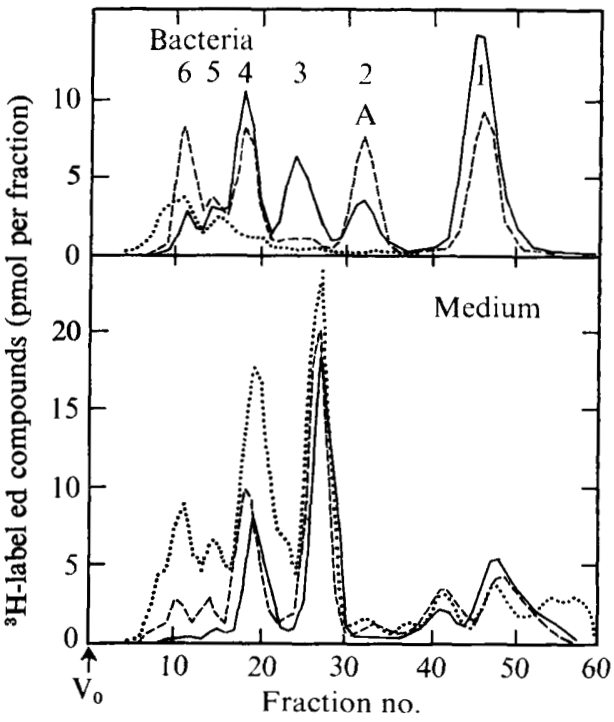

Fig. 3

Fig. 2. Metabolism of $(\mathrm{dl})-5-\left[\mathrm{Me}^{-14} \mathrm{C}\right]$ methyl- $\mathrm{H}_{4} \mathrm{PteGlu}$ by Lactobacillus casei. Experimental conditions were as described in Fig. 1, except that bacteria were preincubated for 15 min with $(d l)-5$ $\left[\mathrm{Me}^{-14} \mathrm{C}\right]$ methyl- $\mathrm{H}_{4}$ PteGlu $\left(0.66 \mu \mathrm{M}\right.$; sp. act., $\left.54 \mathrm{mCi} \mathrm{mmol}{ }^{-1}\right)$ to an intracellular ${ }^{14} \mathrm{C}$-labelled vitamin concentration of $167 \mu \mathrm{M}$. The chromatographic patterns of metabolites at $5(\longrightarrow)$ and $24 \mathrm{~h} \mathrm{(--)}$ are shown.

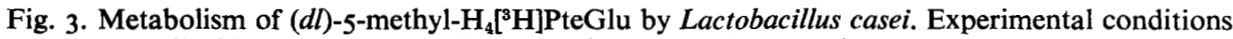
were as described in Fig. I, except that bacteria were preincubated for I $5 \mathrm{~min}$ with $(\mathrm{dl})-5$-methyl$\left.\mathrm{H}_{4}{ }^{3} \mathrm{H}\right]$ PteGlu $\left(0.44 \mu \mathrm{M}\right.$; sp. act., $\left.500 \mathrm{mCi} \mathrm{mmol}^{-1}\right)$ to an intracellular ${ }^{14} \mathrm{C}$-labelled vitamin concentration of $156 \mu \mathrm{M}$. The chromatographic patterns of metabolites at $2(-), 5(---)$ and $24 \mathrm{~h}$ $(\cdots \cdots)$ are shown. The numbers $1-6$ indicate the elution positions of 5 -methyl- $\mathrm{H}_{4} \mathrm{PteGlu}_{1-6}$ $\left(\mathbf{H}_{4}\right.$ PteGlu $\left._{1-6}\right)$ respectively.

known folate standards. Also, no labelled dTMP, methionine or $S$-adenosylmethionine or its major labelled breakdown product, thiomethyladenosine, was detected.

The metabolism of $(\mathrm{dl})-5-\left[\mathrm{Me}-{ }^{14} \mathrm{C}\right]$ methyl- $\mathrm{H}_{4} \mathrm{PteGlu}$ was similar to that observed with (l)-5-[Me-14 C]methyl- $\mathrm{H}_{4}$ PteGlu except that at $5 \mathrm{~h}$, the bacteria and medium still contained a large amount of $5-\left[\mathrm{Me}^{14} \mathrm{C}\right]$ methyl- $\mathrm{H}_{4} \mathrm{PteGlu}$ which presumably represented the $(d)$ isomer of the vitamin (Fig. 2). This unnatural diastereoisomer is transported at approximately the same rate as the natural $(l)$-isomer (Shane \& Stokstad, 1976). In addition, at $5 \mathrm{~h}$ the bacteria contained a labelled metabolite (A, Fig. 2) not detected in bacteria preincubated with $(l)-5$-methyl- $\mathrm{H}_{4}$ PteGlu and by $24 \mathrm{~h}$ most of the $(d)-5-$ methyl- $\mathrm{H}_{4}$ PteGlu had disappeared and another labelled metabolite (B, Fig. 2) had appeared in the bacteria and medium. The elution position of compound $B$ was unaffected by conjugase treatment and it was probably a breakdown product of $(d)-5-$ methyl- $_{4}$ PteGlu. After conjugase treatment, compound $\mathrm{A}$, which eluted at the position of a pteroyldiglutamate, had identical chromatographic properties to authentic $(d)-5$-methyl- $\mathrm{H}_{4}$ PteGlu both on Sephadex G-25 and DEAEcellulose. Compound A was thus identified as $(d)-5-\left[\mathrm{Me}^{14} \mathrm{C}\right]$ methyl- $\mathrm{H}_{4} \mathrm{PteGlu}_{2}$.

The Sephadex G-25 elution profiles obtained with bacteria preincubated with $(d l)-5$ methyl- $\mathrm{H}_{4}\left[{ }^{3} \mathrm{H}\right] \mathrm{PteGlu}$ showed that by $2 \mathrm{~h}$ there was a variety of ${ }^{3} \mathrm{H}$-labelled metabolites (Fig. 3). None of these was similar to metabolites I to VI obtained with $(l)-5-\left[\mathrm{Me}-{ }^{14} \mathrm{C}\right]$ methyl$\mathrm{H}_{4}$ PteGlu (Fig. I) and no ${ }^{3} \mathrm{H}$-labelled material eluted at the void volume. The large 5-methyl- $\mathrm{H}_{4}$ PteGlu peak (Fig. 3) presumably represented the (d)-isomer. After conjugase treatment of the intracellular extract, practically all the ${ }^{3} \mathrm{H}$-label eluted from DEAE- 
cellulose at the position of 5 -methyl- $\mathrm{H}_{4}$ PteGlu and $\mathrm{H}_{4}$ PteGlu. After $2 \mathrm{~h}$ the bacteria contained folates with glutamate chain lengths of up to six, the tetraglutamate ( $l$-isomer) and monoglutamate ( $d$-isomer) predominating. By $5 \mathrm{~h}$, further chain elongation up to pteroylhexaglutamate had occurred (Fig. 3) and over $80 \%$ of the intracellular ${ }^{3} \mathrm{H}$-labelled vitamin was identified (after conjugase treatment) as 5-methyl- $\mathrm{H}_{4} \mathrm{PteGlu}$ and $\mathrm{H}_{4} \mathrm{PteGlu}$. Compound A, observed with bacteria incubated with $(d l)-5-\left[\mathrm{Me}^{14} \mathrm{C}\right]$ methyl- $\mathrm{H}_{4}$ PteGlu (Fig. 2), was also a labelled metabolite of $(d l)-5-$ methyl- $_{4}\left[{ }^{3} \mathrm{H}\right] \mathrm{PteGlu}$ (Fig. 3) and again its chromatographic properties on Sephadex G-25 and DEAE-cellulose, before and after conjugase treatment, indicated that it was $(d)-5-$ methyl- $\mathrm{H}_{4} \mathrm{PteGlu}_{2}$. By $24 \mathrm{~h}$, most of the intracellular folate had been released into the medium. Intracellular folates had glutamate chain lengths

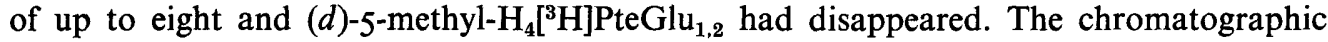
properties of the two major compounds found in the medium at 2, 5 and $24 \mathrm{~h}$ (Fig. 3) were unaffected by conjugase treatment and represented breakdown products, probably ${ }^{3} \mathrm{H}$-labelled $p$-aminobenzoylglutamate and ${ }^{3} \mathrm{H}_{2} \mathrm{O}$. The material eluted in the higher polyglutamate region (fractions 5 to I6, Fig. 3), however, was hydrolysed by conjugase to monoglutamate derivatives. Possibly the presence of these polyglutamates in the medium at $24 \mathrm{~h}$ reflected losses in cell viability under the conditions of the experiment, rather than release by the bacteria.

\section{Methionine metabolism by L. casei}

Although no labelled methionine was detected in bacteria metabolizing 5-[Me- $\left.{ }^{14} \mathrm{C}\right]$ methyl$\mathrm{H}_{4} \mathrm{PteGlu}$, methionine is probably rapidly converted to other compounds. To investigate this possibility further, transport and metabolism studies were carried out with $\mathrm{L}-\left[\mathrm{Me}^{14} \mathrm{C}\right]-$ methionine in an analogous manner to those previously described for $(l)-5$-methyl- $\mathrm{H}_{4} \mathrm{PteGlu}$.

The kinetics of methionine uptake by $L$. casei under these conditions (acetate/phosphate buffer $\mathrm{pH} \mathrm{6,} \mathrm{containing} \mathrm{glucose} \mathrm{and} \mathrm{mercaptoethanol;} \mathrm{see} \mathrm{Methods)} \mathrm{were} \mathrm{best} \mathrm{described} \mathrm{by}$ two uptake systems with $K_{\mathrm{m}}$ values of $0.14 \mu \mathrm{M}$ and $150 \mu \mathrm{M}$ and $V_{\max }$ values of 4.0 and I $20 \mu \mathrm{M} \mathrm{min}{ }^{-1}$, respectively. No attempt was made to optimize the conditions for uptake or to ascertain if mercaptoethanol in the buffer had any effect on transport.

If $L$. casei metabolizes 5 -methyl- $\mathrm{H}_{4}$ PteGlu by transfer of the methyl group to homocysteine, then a similar pattern of ${ }^{14} \mathrm{C}$-labelled metabolites would be expected with $\left[\mathrm{Me}^{14} \mathrm{C}\right]-$ methionine, as $90 \%$ of the $(l)-5-\left[\mathrm{Me}^{14} \mathrm{C}\right]$ methyl- $\mathrm{H}_{4} \mathrm{PteGlu}$ in preincubated cells was metabolized within I h (Fig. I). However, when bacteria were preincubated with $\left[\mathrm{Me}^{-14} \mathrm{C}\right]$ methionine to about the same intracellular levels and reincubated in fresh buffer, over $80 \%$ of the intracellular label was not extracted with boiling buffer, compared with about $20 \%$ when bacteria were incubated with ${ }^{14} \mathrm{C}$-labelled folate.

The Sephadex G-25 elution profiles obtained with extracts from bacteria incubated with $\mathrm{L}-\left[\mathrm{Me}^{-14} \mathrm{C}\right] \mathrm{methionine}$ (Fig. 4) were very different from the profiles obtained with bacteria metabolizing (l)-5-[Me-14 $\mathrm{C}]$ methyl- ${ }_{4}$ PteGlu (Fig. I).

\section{Properties of labelled bacterial metabolites not solubilized by buffer extraction}

Various treatments were tried to solubilize the ${ }^{14} \mathrm{C}$-labelled metabolites that were not extracted by boiling buffer from $\mathrm{L}$. casei metabolizing $(l)-5-\left[\mathrm{Me}^{-14} \mathrm{C}\right]$ methyl- $\mathrm{H}_{4} \mathrm{PteGlu}$. About $60 \%$ of the label was solubilized after treatment with pancreatic RNAase, about I I \% by DNAase, and the remainder by heating with I M-perchloric acid. None of these treatments effectively solubilized ${ }^{14} \mathrm{C}$-labelled metabolites derived from $\mathrm{L}-\left[\mathrm{Me}^{-14} \mathrm{C}\right]$ methio-

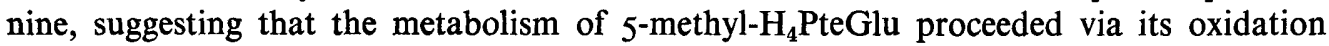
with the incorporation of its one-carbon moiety into purines and pyrimidines rather than via methionine synthesis. To examine this conclusion further, $L$. casei was incubated with labelled purines and pyrimidines, and the metabolites derived from these bases were

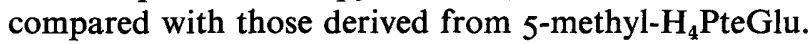




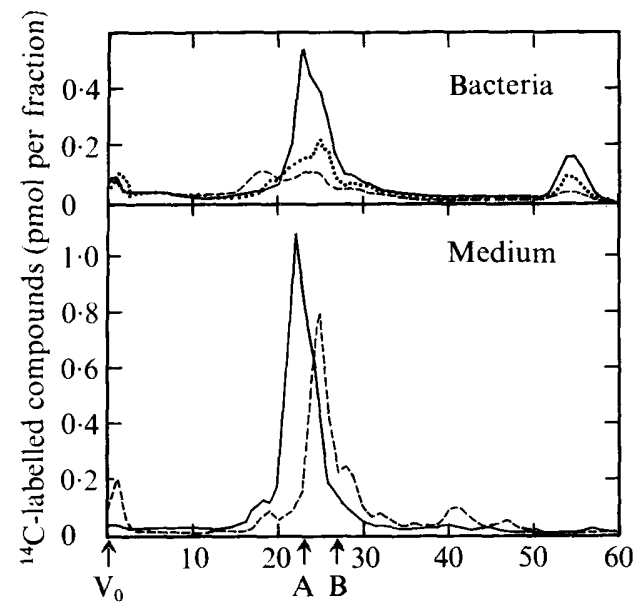

Fraction no.

Fig. 4

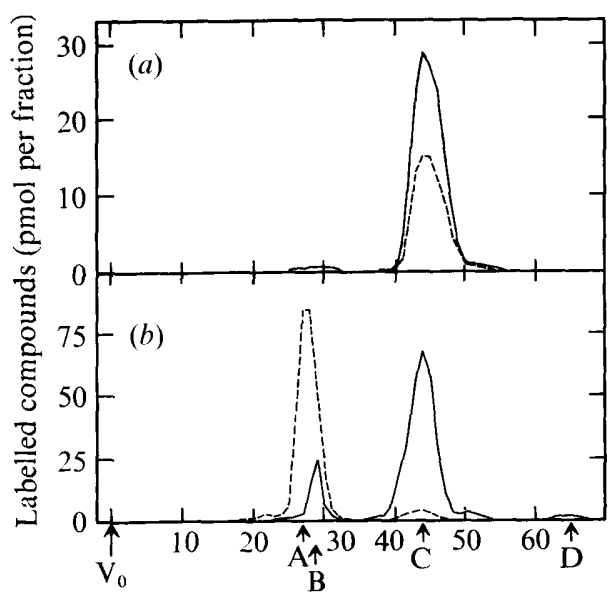

Fraction no.

Fig. 5

Fig. 4. Metabolism of $\mathrm{L}-\left[\mathrm{Me}^{-14} \mathrm{C}\right]$ methionine by Lactobacillus casei. Experimental conditions were as described in Fig. I, except that bacteria were preincubated for $\mathrm{I} 5 \mathrm{~min}$ with $\mathrm{L}-\left[\mathrm{Me}-{ }^{14} \mathrm{C}\right]$ methionine $(7 \mu \mathrm{M})$ to an intracellular concentration of $\mathrm{I} 38 \mu \mathrm{M}$. The chromatographic patterns of ${ }^{14} \mathrm{C}$-labelled metabolites in the intracellular and extracellular extracts at I $(-), 2(\cdots \cdots)$ and $5 \mathrm{~h}(---)$ are shown. Standards used to calibrate the column were methionine (A) and ${ }^{3} \mathrm{H}_{2} \mathrm{O}(B)$.

Fig. 5. Sephadex G-25 chromatography of labelled metabolites solubilized by RNAase $T_{2}$ treatment of insoluble material derived after extraction of Lactobacillus case $i$ with boiling buffer. Experimental conditions were as described in Methods. Labelled metabolites solubilized by RNAase treatment of cell debris derived from $10 \mathrm{mg}$ dry wt bacteria were chromatographed on Sephadex G-25 as described in Fig. I. (a) Patterns of ${ }^{14} \mathrm{C}$-labelled metabolites derived from $(l)-5-\left[M e-{ }^{14} \mathrm{C}\right]-$ methyl- $\mathrm{H}_{4}$ PteGlu after incubating bacteria in the presence (--) and absence $(-)$ of unlabelled adenosine $(0.1 \mathrm{mM})$. (b) Patterns of ${ }^{3} \mathrm{H}$-labelled metabolites of $\left[{ }^{3} \mathrm{H}\right]$ adenine $(-)$ and $\left[{ }^{3} \mathrm{H}\right]$ uracil (--). Standards used to calibrate the columns were $3^{\prime}$-UMP (A), ${ }^{3} \mathrm{H}_{2} \mathrm{O}$ (B), $3^{\prime}$-AMP (C), $3^{\prime}-\mathrm{GMP}$ (C) and adenine (D).

\section{Table I. Distribution of labelled metabolites in Lactobacillus casei extracts after

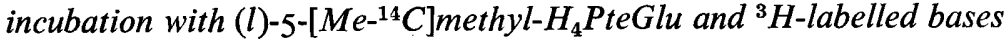

Bacteria $\left(0.2 \mathrm{mg}\right.$ dry wt ml-1 in $50 \mathrm{mM}^{-1} \mathrm{~K}_{2} \mathrm{HPO}_{4} / 100 \mathrm{~mm}$-sodium acetate adjusted to pH 6 with $\mathrm{H}_{3} \mathrm{PO}_{4}$, and containing $1 \%$ glucose and $5 \mathrm{mM}$-mercaptoethanol) were preincubated with the ${ }^{3} \mathrm{H}-$ labelled base $\left(5 \mu \mathrm{Ci} \mathrm{ml}^{-1}\right)$ for $2 \mathrm{~h}$ and with $(l)-5-\left[\mathrm{Me}^{14} \mathrm{C}\right]$ methyl-H ${ }_{4} \mathrm{PteGlu}(0.5 \mu \mathrm{M})$ for $15 \mathrm{~min}$ and were then resuspended $\left(0.4 \mathrm{mg} \mathrm{ml}^{-1}\right)$ and reincubated in fresh buffer for $2 \mathrm{~h}$. Extracts were prepared as described in Methods. Results are expressed as pmol labelled compounds (mg dry wt bacteria) ${ }^{-1}$.

Extract

Intracellular Insoluble material

(i) RNAase $T_{2}$ extract

(ii) Residue Medium

Total

\begin{tabular}{cccccc}
\multicolumn{5}{c}{ Labelled substrate } \\
$\begin{array}{c}\text { 5-Methyl- } \\
\text { H}_{4} \text { PteGlu* }\end{array}$ & Adenine & Guanine & Uracil & Cytosine & Thymine \\
250 & 65 & 531 & 66 & I & 107 \\
25 & 74 & 747 & 72 & I & 7 \\
I6 & 14 & 108 & 16 & 0 & 405 \\
250 & 25 & 282 & 29 & 5 & 77 \\
544 & 176 & 1660 & 184 & 8 & 596
\end{tabular}

* Values for the labelled metabolites of $(l)-5-\left[\mathrm{Me}^{-14} \mathrm{C}\right]$ methyl- $\mathrm{H}_{4} \mathrm{PteGlu}$ represent the mean of five experiments. 


\section{Metabolism of purine and pyrimidine bases}

Tritium-labelled bases, with the exception of cytosine, were rapidly taken up by $L$. casei. Initial uptake rates under the conditions described for methionine transport were $10 \cdot 1 \mu \mathrm{M}$ $\min ^{-1}$ for adenine (initial concentration in medium $0.27 \mu \mathrm{M}$ ), $86.8 \mu \mathrm{M} \mathrm{min}$ min $^{-1}$ for guanine (I.0 $\mu \mathrm{M}), \mathrm{I} 3.8 \mu \mathrm{M} \mathrm{min}^{-1}$ for uracil $(0.19 \mu \mathrm{M}), 0.08 \mu \mathrm{M} \mathrm{min}^{-1}$ for cytosine $(0.18 \mu \mathrm{M})$, and $10.4 \mu \mathrm{M} \mathrm{m^{-1 }}$ for thymine $(0.5 \mu \mathrm{M})$. The poor uptake of cytosine was not investigated further but may have been a result of ${ }^{3} \mathrm{H}$ exchange at the 5-position due to metabolism.

Lactobacillus casei was preincubated for $2 \mathrm{~h}$ with the ${ }^{3} \mathrm{H}$-labelled bases and for $15 \mathrm{~min}$ with $(l)-5-\left[\mathrm{Me}^{-14} \mathrm{C}\right]$ methyl- $\mathrm{H}_{4} \mathrm{PteGlu}$, and was then resuspended in fresh buffer and incubated for $2 \mathrm{~h}$. The distribution of radioactive label in the bacteria and medium at this time is shown in Table I. Approximately $60 \%$ of the non-extractable bacterial ${ }^{14} \mathrm{C}$-label (insoluble material, Table I) and over $80 \%$ of the adenine, guanine, and uracil metabolites were solubilized by RNAase $\mathrm{T}_{2}$, while less than $2 \%$ of the thymine metabolites were solubilized by this treatment. When the above experiment was repeated with unlabelled nucleosides $(0 . \mathrm{I} \mathrm{mM})$ in the preincubation and resuspension buffers, ${ }^{14} \mathrm{C}$-label in the RNAase extract was reduced in the presence of adenosine while label in the fraction not solubilized by RNAase was reduced in the presence of thymidine. Uridine had no effect. The insoluble material thus appeared to contain denatured RNA and DNA. This was confirmed by Sephadex G-25 chromatography as ${ }^{14} \mathrm{C}$-labelled metabolites solubilized by RNAase treatment co-eluted with standard $3^{\prime}$-AMP and $3^{\prime}$-GMP (Fig. $5 a$ ) and at the same position as the labelled adenine derivative solubilized by this treatment (Fig. $5 b$ ). The early-eluting labelled adenine metabolite (Fig. $5 b$, fraction 29) was ${ }^{3} \mathrm{H}_{2} \mathrm{O}$. Two-dimensional thin-layer chromatography demonstrated that the ${ }^{14} \mathrm{C}$-label was incorporated into the purine ring. All the ${ }^{14} \mathrm{C}$-label chromatographed at the positions of $3^{\prime}$-AMP and $3^{\prime}$-GMP and no methylated purine derivatives or 3'-TMP were detected.

The Sephadex G-25 chromatographic profiles obtained with bacterial and extracellular extracts (Table I) are shown in Fig. 6. The ${ }^{14} \mathrm{C}$-labelled peak I derived from $(l)-5-\left[\mathrm{Me}-{ }^{14} \mathrm{C}\right]-$ methyl- $\mathrm{H}_{4}$ PteGlu coincided with a labelled metabolite derived from uracil (Fig. $6 c$, fraction I8) and thymine (Fig. $6 d$, fraction I8) and eluted just prior to an adenine derivative (Fig. $6 a$, fraction 19). Material in peak I was a thymidylate derivative as a variety of uracil derivatives were detected which were not labelled with ${ }^{14} \mathrm{C}$ (Fig. 6c, fractions 10, I4) and its synthesis was decreased when bacteria were preincubated with unlabelled thymidine ( $0.1 \mathrm{mM})$ but was unaffected by preincubation with unlabelled uridine (0.I mM). Peak I co-eluted from Sephadex G-25 with UTP, CTP and dTTP. However, the ${ }^{14} \mathrm{C}$-labelled compound and $\left[{ }^{3} \mathrm{H}\right]$ thymine metabolite in this peak (Fig. $6 d$ ) eluted from DEAE-cellulose at the position of dTMP (Fig. $7 a$, fraction ${ }^{15}$ ). No $\left[{ }^{14} \mathrm{C}\right]-$ or $\left[{ }^{3} \mathrm{H}\right]$ dTTP was detected. With bacteria incubated with $\left[{ }^{3} \mathrm{H}\right]$ uracil, about $90 \%$ of the ${ }^{3} \mathrm{H}$-label in peak I (Fig. $6 c$ ) eluted from DEAEcellulose at the position of dTMP and about $10 \%$ at the position of UTP. Peak I therefore contained a thymidylate derivative. It also contained a more electronegative ${ }^{14} \mathrm{C}$-labelled compound (Fig. $7 a$, fraction 40 ) which co-eluted with a $\left[{ }^{3} \mathrm{H}\right]$ purine derivative (Fig. $6 a$, fraction I9).

The remaining ${ }^{14} \mathrm{C}$-labelled peaks, with the exception of unmetabolized $(l)-5-\left[\mathrm{Me}^{-14} \mathrm{C}\right]-$ methyl- $\mathrm{H}_{4} \mathrm{PteGlu}$, corresponded almost entirely to purine derivatives (Fig. $6 a, b$ ). The major intracellular peak derived from [ $\left.{ }^{3} \mathrm{H}\right]$ adenine was contaminated with ${ }^{3} \mathrm{H}_{2} \mathrm{O}$ (Fig. $6 a$, fraction 29). This was not observed in the extracellular extract (Fig. 6b) as the medium was concentrated and desalted before chromatography by absorption and elution from active charcoal. ${ }^{14} \mathrm{C}$-Labelled material not absorbed by charcoal from the medium eluted at the position of formaldehyde (Fig. 6b, fraction 28) and condensed with dimedone.

Rechromatography of labelled bacterial compounds in peaks II to V (Fig. $6 a$ ) on DEAEcellulose (Fig. $7 b, c, d, e$ ), in this case with bacteria preincubated with guanine instead of adenine, demonstrated that nearly all the ${ }^{14} \mathrm{C}$-labelled compounds were purine metabolites. 


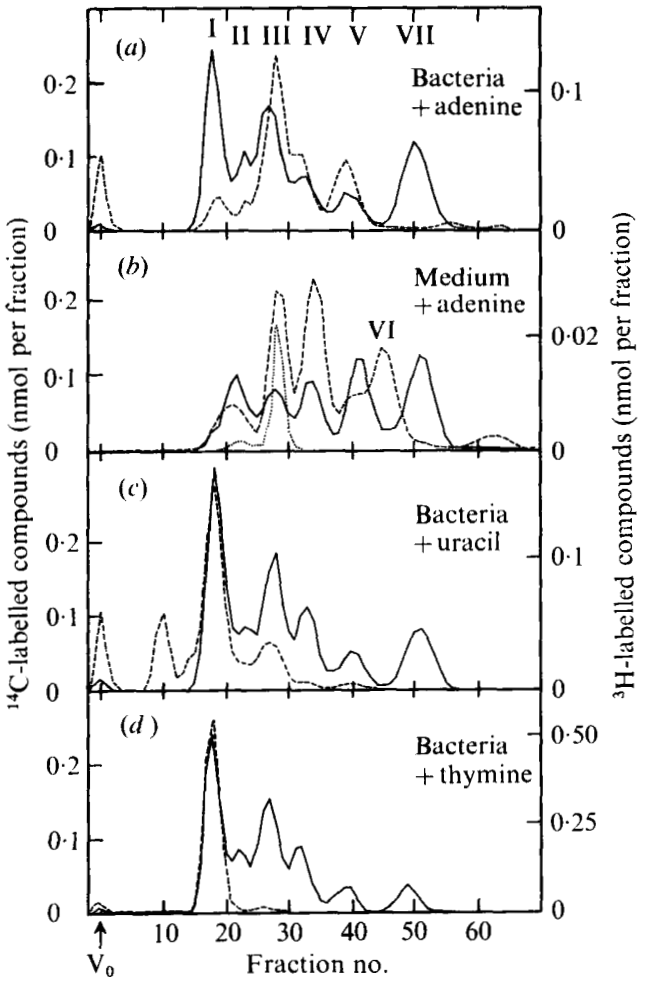

Fig. 6

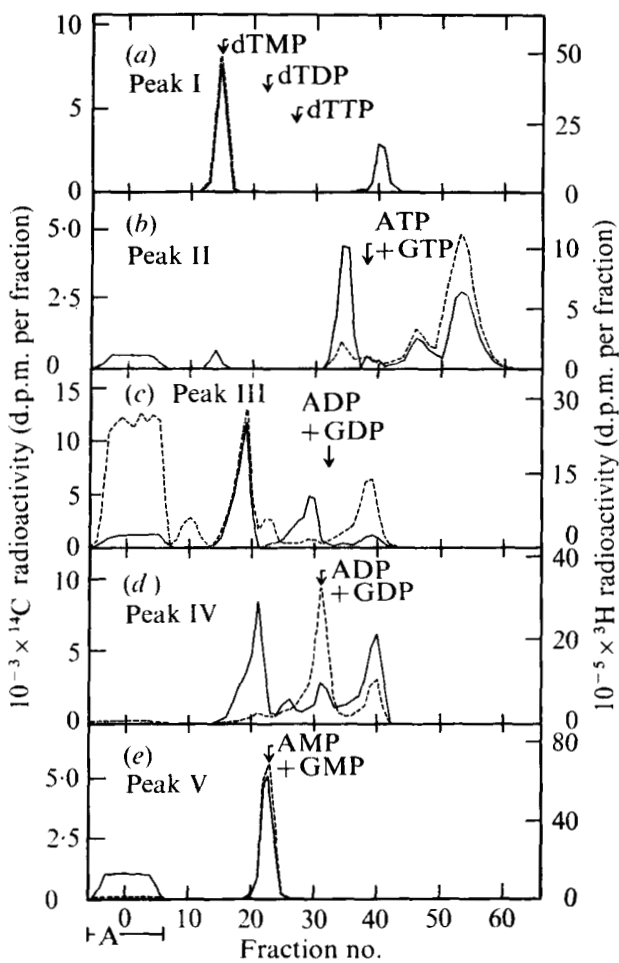

Fig. 7

Fig. 6. Metabolism of $(l)-5-\left[\mathrm{Me}^{14} \mathrm{C}\right]$ methyl- $\mathrm{H}_{4} \mathrm{PteGlu}$ and ${ }^{3} \mathrm{H}$-labelled bases by Lactobacillus casei. Experimental conditions were as described in Table 1 . Intracellular and extracellular extracts (equivalent to $20 \mathrm{mg}$ dry wt bacteria), obtained by incubating $L$. casei with $(l)-5-\left[M e-{ }^{14} \mathrm{C}\right]$ methyl$\mathrm{H}_{4}$ PteGlu and ${ }^{3} \mathrm{H}$-labelled bases (as indicated), were chromatographed on Sephadex G-25 as described in Fig. $\mathrm{I}:{ }^{14} \mathrm{C}$-labelled compounds (-); ${ }^{3} \mathrm{H}$-labelled compounds (- - ). Extracellular extracts $(b)$ were concentrated by absorption and elution from active charcoal as described in Methods; the elution pattern of ${ }^{14} \mathrm{C}$-labelled metabolites not absorbed by charcoal is also shown $(\cdots)$. The columns were precalibrated with standards whose elution positions were as follows: dTTP (fraction 18), UTP (18), CTP (18), NADP (22), dTMP (25), ATP (26), ADP (32), FAD (34), NAD (34), AMP (4I), GMP (4I), adenosine (53), adenine (64), formate (25), formaldehyde (26), ${ }^{3} \mathrm{H}_{2} \mathrm{O}$ (28), 10-formyl- $\mathrm{H}_{4}$ PteGlu (34) and 5-methyl- $\mathrm{H}_{4}$ PteGlu (5I).

Fig. 7. DEAE-cellulose chromatography of labelled metabolites of $(l)-5-\left[\mathrm{Me}^{14} \mathrm{C}\right] \mathrm{methyl}^{-\mathrm{H}_{4} \mathrm{PteGlu}}$ and ${ }^{3} \mathrm{H}$-labelled bases. Experimental conditions were as described in Fig. 6. Individual peak fractions obtained by Sephadex G-25 chromatography of intracellular extracts (Fig. 6) were diluted to $30 \mathrm{ml}$ with $\mathrm{H}_{2} \mathrm{O}$ and applied to $25 \times 0.9 \mathrm{~cm}$ DEAE-cellulose columns equilibrated with $0.0 \mathrm{I} \mathrm{M}-$ phosphate buffer pH 6. Each column was eluted by an exponential phosphate gradient formed with $0.01 \mathrm{M}$-phosphate buffer (100 ml) in a closed mixing chamber attached to a reservoir containing $0.5 \mathrm{M}$-phosphate buffer $\mathrm{pH}$ 6. Fractions $(3.0 \mathrm{ml})$ are numbered from the beginning of the elution: ${ }^{14} \mathrm{C}$-labelled compounds $(-) ;{ }^{3} \mathrm{H}$-labelled compounds $(---)$. (a) Elution pattern obtained with intracellular labelled material derived from $(l)-5-\left[M e-{ }^{14} \mathrm{C}\right]$ methyl- $\mathrm{H}_{4}$ PteGlu and $\left[{ }^{3} \mathrm{H}\right]$ thymine that eluted at the position of peak I from Sephadex G-25 (Fig. 6d, fraction 18). (b-e) Equivalent data for peaks II-V, respectively, obtained from bacteria incubated with $(l)-5-\left[\mathrm{Me}^{-14} \mathrm{C}\right] \mathrm{methyl}-$ $\mathrm{H}_{4}$ PteGlu and $\left[{ }^{3} \mathrm{H}\right]$ guanine (equivalent to Fig. $6 a$, fractions $23,27,33$ and 39 , respectively). The elution positions of unlabelled standards applied with the samples are indicated on the figures. The elution positions obtained with other standards chromatographed under similar conditions were: dTMP (fraction I5), UMP (16), CMP (16), dTDP (22), UDP (22), CDP (23), AMP (23), GMP (23), dTTP (27), UTP (28), CTP (28), ADP (3I), GDP (3I), ATP (36), formate (20), Io-formyl- $\mathrm{H}_{4}$ PteGlu (23), 5 -methyl- $\mathrm{H}_{4}$ PteGlu (38) and $\mathrm{H}_{4} \mathrm{PteGlu}(43)$. Bases, nucleosides, ${ }^{3} \mathrm{H}_{2} \mathrm{O}$, formaldehyde, methionine, and $S$-adenosylmethionine eluted at $\mathrm{A}$, which is the elution position of unabsorbed compounds. 
Although differences in specific labelling due to different incubation times and differences in initial metabolic routes were observed, practically all the ${ }^{3} \mathrm{H}-$ and ${ }^{14} \mathrm{C}$-label co-eluted.

The major purine metabolites in peaks II to IV were not further identified (Fig. $7 b, c, d$ ). Peak III contained some ATP/GTP (Fig. 7c, fraction 39) and labelled material not absorbed by the column consisted of ${ }^{3} \mathrm{H}_{2} \mathrm{O}$ and $\left[{ }^{14} \mathrm{C}\right]$ formaldehyde. Peak IV contained some ADP/GDP (Fig. 7d, fraction 3I) while most of the labelled material in peak $\mathrm{V}$ was identified as AMP/GMP (Fig. $7 e$, fraction 23). The overall distribution of ${ }^{14} \mathrm{C}$-label in this experiment was as follows: thymidylate derivatives ( $15 \%)$, purine derivatives $(43 \%)$,

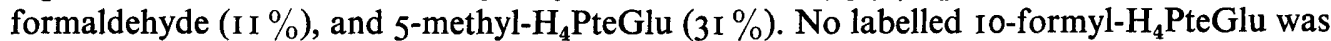
detected. Practically all the labelled formaldehyde was found in the medium and presumably resulted from degradation of 5,10-methylene- $\mathrm{H}_{4} \mathrm{PteGlu}$ under the conditions of this experiment.

\section{DISCUSSION}

Although pteroylmono- and pteroyldiglutamates are the forms preferred for transport of folate (Shane \& Stokstad, 1975, I976), in practically every case investigated pteroylpolyglutamates are the predominant, if not the only, intracellular forms of the vitamin (Baugh, Braverman \& Nair, 1974; Brown, Davidson \& Scott, 1974a; Buehring et al., I974; Houlihan \& Scott, 1972; LaVoie et al., 1975; Leslie \& Baugh, 1974; Shin, Buehring \& Stokstad, I974a; Shin et al., 1972b). In $L$. casei, octoglutamates predominate if the organism is grown on low levels of folate (Brown et al., 1974b; Buehring et al., 1974); if high levels of folate are supplied in the medium, shorter chain length folates are found, predominantly the tetraglutamate derivative (Baugh et al., 1974). Pteroylpolyglutamates were originally thought to be intracellular storage forms of the vitamin. However, in vitro studies have shown them to be equally or more effective than monoglutamates as enzyme substrates. One of these enzymes, a $B_{12}$-independent methionine synthetase, which is present in some micro-organisms (Taylor \& Weissbach, 1973; Whitfield et al., 1970) but not in mammalian tissues (Cheng et al., 1975; Coward et al., 1975), either only functions with folylpolyglumate substrates or utilizes the monoglutamate derivative extremely poorly. In vivo studies have also shown that while the rate-limiting step in the utilization of pteroylpolyglutamates by $L$. casei is their transport into the cell, once taken up, they are more effectively utilized for growth than the monoglutamate derivatives (Shane \& Stokstad, 1976). The rate-limiting step in the utilization of monoglutamates is some step other than transport.

Lactobacillus casei preincubated with $(l)-5-\left[\mathrm{Me}^{-14} \mathrm{C}\right]$ methyl- $\mathrm{H}_{4} \mathrm{PteGlu}$ metabolized this compound to a variety of labelled metabolites which were non-folate in nature. These were identified as purine and thymidylate derivatives by co-chromatography on Sephadex G-25 and DEAE-cellulose with metabolites derived from $\left[{ }^{3} \mathrm{H}\right]$ thymine and $\left[{ }^{3} \mathrm{H}\right]$ purines. Delk \& Rabinowitz (1975) have shown that folate is involved in the methylation of uridine in RNA of Streptococcus faecalis. We did not detect any labelled $3^{\prime}-\mathrm{TMP}$ in $L$. casei RNA hydrolysates or any methylated purines, demonstrating that the one-carbon moiety of $5-\left[\mathrm{Me}^{-14} \mathrm{C}\right]$ methyl- $\mathrm{H}_{4} \mathrm{PteGlu}$ was incorporated into the purine ring. This does not rule out the possibility that folate is involved in the methylation of RNA in L. casei as our technique was probably not sensitive enough to detect small amounts of labelled methylated bases. In respect to this, we were unable to detect labelled methylated bases in the RNA of cells incubated with $\left[{ }^{3} \mathrm{H}\right]$ adenine or $\left[{ }^{3} \mathrm{H}\right]$ uracil.

No labelled methionine was detected in these experiments and completely different labelled metabolites were obtained with bacteria incubated with $\mathrm{L}-\left[\mathrm{Me}^{-14} \mathrm{C}\right]$ methionine. These data indicate that the initial step in the metabolism of 5 -methyl- $\mathrm{H}_{4} \mathrm{PteGlu}$ by $L$. casei proceeds via its oxidation rather than through methionine synthesis. This is different from mammalian metabolism where the one-carbon moiety of 5 -methyl- $\mathrm{H}_{4} \mathrm{PteGlu}$ is transferred to methionine (Nixon et al., 1973) and oxidation to 5, I0-methylene- $\mathrm{H}_{4} \mathrm{PteGlu}$ does not occur under physiological conditions (Kutzbach \& Stokstad, I97I). 
Although no labelled pteroylpolyglutamates were detected in cells incubated with (l)-5-[Me-14 $\mathrm{C}]$ methyl- $\mathrm{H}_{4}$ PteGlu, $(d)-5-\left[\mathrm{Me}^{-14} \mathrm{C}\right]$ methyl- $\mathrm{H}_{4}$ PteGlu was slowly metabolized to the diglutamate form, but not to higher polyglutamates. In human lymphocytes, however, labelled polyglutamates were not formed from $(\mathrm{dl})-5-\left[\mathrm{Me}^{14} \mathrm{C}\right] \mathrm{methyl}-\mathrm{H}_{4} \mathrm{PteGlu}(\mathrm{LaVoie}$, Tripp \& Hoffbrand, 1974), although in this case the (d)-isomer may not have been transported. ( $d l)$-5-Methyl- $\mathrm{H}_{4}\left[{ }^{3} \mathrm{H}\right] \mathrm{PteGlu}$ was metabolized to labelled polyglutamate forms, mainly to $(l)-5-$ methyl- $\mathrm{H}_{4} \mathrm{PteGlu}_{n}$ and $\mathrm{H}_{4} \mathrm{PteGlu}_{n}(n \leqslant 8)$ and $(d)-5-$-methyl- $\mathrm{H}_{4} \mathrm{PteGlu}_{2}$, suggesting that $(l)-5-$ methyl- $\mathrm{H}_{4} \mathrm{PteGlu}$ is not a substrate for the $L$. casei folylpolyglutamate synthetase, and that removal of its one-carbon moiety is necessary before folylpolyglutamates can be synthesized.

Little is known of the specificity of the enzymes responsible for the formation of pteroylpolyglutamates. Sakami et al. (1973) reported the presence of two enzymes in Neurospora crassa, one specific for the formation of pteroyldiglutamate and the other for synthesis of longer chain polyglutamates and both specific for $\mathrm{H}_{4} \mathrm{PteGlu}_{n}$ derivatives. Escherichia coli contains a $\mathrm{IO}$-formyl- $\mathrm{H}_{4} \mathrm{PteGlu}_{2}$ synthetase (Masurekar \& Brown, 1975) which will also utilize a variety of other pteroylmonoglutamates but not 5 -methyl- $\mathrm{H}_{4} \mathrm{PteGlu}$ while Gawthorne \& Smith (I973), in studies with mixed folate diastereoisomers, reported that 5-formyl- $\mathrm{H}_{4} \mathrm{PteGlu}$, 5-methyl- $\mathrm{H}_{4} \mathrm{PteGlu}$ and $\mathrm{H}_{4} \mathrm{PteGlu}$ were substrates for the enzyme in sheep liver. Shorter chain length polyglutamates of PteGlu in L. casei (Shin, Buehring \& Stokstad, 1974b) and methotrexate (Baugh, Krumdieck \& Nair, 1973; Shin et al., 1974b) in rat liver have also been reported. In a previous study (Shane \& Stokstad, I975), we showed that $L$. casei metabolized low levels of PteGlu to a variety of $\mathbf{H}_{4}$ PteGlu polyglutamates. All these data suggest the presence of two synthetases, with the diglutamate-forming enzyme having a specificity for a variety of pteroylmonoglutamates and the higher polyglutamate synthetase having a specificity for $\mathrm{H}_{4} \mathrm{PteGlu} \mathrm{u}_{n}$.

This research was supported by United States Public Health Service Grant AM-08I 7 I from the National Institutes of Health. B.S. is indebted to the Wellcome Trust for a travel grant. We would like to thank Joe Watson for his excellent technical assistance, and Dr Anne Delk, Department of Biochemistry, for helpful discussion.

\section{REFERENCES}

Baugh, C. M., Braverman, E. \& NaIr, M. G. (1974). The identification of poly- $\gamma$-glutamyl chain lengths in bacterial folates. Biochemistry I3, 4952-4957.

BaUgh, C. M., KRUMdieck, C. L. \& NaIr, M. G. (1973). Polygammaglutamyl metabolites of methotrexate. Biochemical and Biophysical Research Communications 52, 27-34.

Brown, J. P., Davidson, G. E. \& Scott, J. M. $(1974 a)$. The identification of the forms of folate found in the liver, kidney and intestine of the monkey and their biosynthesis from exogenous pteroylglutamate (folic acid). Biochimica et biophysica acta 343, 78-88.

Brown, J. P., DobBs, F., Davidson, G. E. \& ScotT, J. M. (I974b). Microbial synthesis of folate polyglutamates from labelled precursors. Journal of General Microbiology 84, 163-172.

Buehring, K. U., TAmura, T. \& STokstad, E. L. R. (1974). Folate coenzymes of Lactobacillus casei and Streptococcus faecalis. Journal of Biological Chemistry 249, 108 I-1089.

Burton, E. G. \& Metzenberg, R. L. (1975). Regulation of methionine biosynthesis in Neurospora crassa. Archives of Biochemistry and Biophysics 168, 219-229.

Cheng, F. W., Shane, B. \& Stokstad, E. L. R. (1975). Pentaglutamate derivatives of folate as substrates for rat liver tetrahydropteroylglutamate methyltransferase and 5,10-methylenetetrahydrofolate reductase. Canadian Journal of Biochemistry 53, 1020-1027.

Cleland, W. W. (1967). The statistical analysis of enzyme kinetic data. Advances in Enzymology 29, $\mathrm{I}-33$.

Contractor, S. F. \& Shane, B. (1969). Quantitation of $\left[{ }^{14} \mathrm{C}\right]-$ and $\left[{ }^{3} \mathrm{H}\right]$ pyridoxol by scintillation autography of thin layer chromatograms. Journal of Chromatography 41, 483-486.

Coward, J. K., Parameswaran, K. N., Cashmore, A. R. \& BERTINO, J. R. (1974). 7,8-Dihydropteroyl oligo- $\gamma$-L-glutamates: synthesis and kinetic studies with purified dihydrofolate reductase from mammalian sources. Biochemistry r3, 3899-3903. Coward, J. K., Chello, P. L., Cashmore, A. R., Parameswaran, K. N., DeAngelis, L. M. \& BerTINO, J. R. (1975). 5-Methyl-5,6,7,8-tetrahydropteroyl oligo- $\gamma$-L-glutamates: synthesis and kinetic 
studies with methionine synthetase from bovine brain. Biochemistry 14, I 548-1552.

Curthoys, N. P. \& Rabinowitz, J. C. (1972). Formyltetrahydrofolate synthetase. Binding of folate substrates and kinetics of the reverse reaction. Journal of Biological Chemistry 247, 1965-197I.

DelK, A. S. \& Rabinowitz, J. C. (1975). Biosynthesis of ribosylthymine in the transfer RNA of Streptococcus faecalis: a folate-dependent methylation not involving $S$-adenosylmethionine. Proceedings of the National Academy of Sciences of the United States of America 72, 528-530.

Galivan, T. (197I). Discussion on folate compounds - chemistry and enzymology. Annals of the New York Academy of Sciences r86, 83.

GAwThorne, J. M. \& SMith, R. M. (1973). The synthesis of pteroylpolyglutamates by sheep liver enzymes in vitro. Biochemical Journal r36, 295301.

Goldmark, P. J. \& LinN, S. (1970). An endonuclease activity from Escherichia coli absent from certain rec- strains. Proceedings of the National Academy of Sciences of the United States of America 67, 434-44I.

Houlihan, C. M. \& ScotT, J. M. (1972). The identification of pteroylpentaglutamate as the major folate derivative in rat liver and the demonstration of its biosynthesis from exogenous $\left[{ }^{3} \mathrm{H}\right]$ pteroylglutamate. Biochemical and Biophysical Research Communications 48, 1675-168I.

KePEs, A. \& Cohen, G. N. (1962). Permeation. In The Bacteria, vol. 4, pp. 179-222. Edited by I. C. Gunsalus and R. Y. Stanier. New York: Academic Press.

KISLIUK, R. L. (197I). Discussion on folate compounds - chemistry and enzymology. Annals of the New York Academy of Sciences 186, 83.

Kisliuk, R. L., Gaumont, Y. \& Baugh, C. M. (1974). Polyglutamyl derivatives of folate as substrates and inhibitors of thymidylate synthetase. Journal of Biological Chemistry 249, 41004103.

KlagsBrun, M. (1973). An evolutionary study of the methylation of transfer and ribosomal ribonucleic acid in prokaryote and eukaryote organisms. Journal of Biological Chemistry 248, 26122620.

Kutzbach, C. \& Stokstad, E. L. R. (1971). Mammalian methylenetetrahydrofolate reductase. Biochimica et biophysica acta 250, 459-477.

LaVoie, A., Tripp, E. \& HoffBrand, A. V. (1974). The effect of vitamin $B_{12}$ deficiency on methylfolate metabolism and pteroylpolyglutamate synthesis in human cells. Clinical Science and Molecular Medicine 47, 617-630.

LaVoie, A., Tripp, E., Parsa, K. \& Hoffbrand, A. V. (1975). Polyglutamate forms of folate in resting and proliferating mammalian tissues. Clinical Science and Molecular Medicine 48, 67-73.

LESLIE, G. I. \& BAUGH, C. M. (1974). The uptake of pteroyl[ $\left[{ }^{14} \mathrm{C}\right]$ glutamic acid into rat liver and its incorporation into the natural pteroyl poly- $\gamma$ glutamates of that organ. Biochemistry 13,4957496r.

Masurekar, M. \& Brown, G. M. (I975). Partial purification and properties of an enzyme from Escherichia coli that catalyzes the conversion of glutamic acid and 10-formyltetrahydropteroyl- glutamic acid to 10-formyltetrahydropteroyl- $\gamma$ glutamylglutamic acid. Biochemistry 14, 24242430.

Nishimura, S. (1972). Minor components in transfer RNA: their characterization, location, and function. Progress in Nucleic Acid Research and Molecular Biology 12, 49-85.

Nixon, P. F., Slutsky, G., Nahas, A. \& Bertino, J. R. (1973). The turnover of folate coenzymes in murine lymphoma cells. Journal of Biological Chemistry 248, 5932-5936.

Powers, S. G. \& SNELl, E. E. (1976). Ketopantoate hydroxymethyltransferase. II. Physical, catalytic, and regulatory properties. Journal of Biological Chemistry 25I, 3786-3793.

Sakami, W., Ritari, S. J., Black, C. W. \& Rzepka, J. (I973). Polyglutamate synthesis by Neurospora crassa. Federation Proceedings 32, 47I.

Salem, A. R., Pattison, J. R. \& Foster, M. A. (1972). Folic acid and the methylation of homocysteine by Bacillus subtilis. Biochemical Journal 126, 993I004.

Shane, B. \& Stokstad, E. L. R. (1975). Transport and metabolism of folates by bacteria. Journal of Biological Chemistry 250, 2243-2253.

Shane, B. \& STOKSTAD, E. L. R. (I976). Transport and utilization of methyltetrahydrofolates by Lactobacillus casei. Journal of Biological Chemistry 25I, 3405-34IO.

Shin, Y. S., Buehring, K. U. \& Stokstad, E. L. R. $(1972 a)$. Separation of folic acid compounds by gel chromatography on Sephadex G-I 5 and G-25. Journal of Biological Chemistry 247, 7266-7269.

Shin, Y. S., Williams, M. A. \& Stokstad, E. L. R. $(1972 b)$. Identification of folic acid compounds in rat liver. Biochemical and Biophysical Research Communications 47, 35-43.

Shin, Y. S., BUEHRING, K. U. \& STOKSTAD, E. L. R. (1974a). Studies of folate compounds in nature. Folate compounds in rat kidney and red blood cells. Archives of Biochemistry and Biophysics 163, $211-224$.

Shin, Y. S., Buehring, K. U. \& Stokstad, E. L. R. $(1974 b)$. The metabolism of methotrexate in Lactobacillus case $i$ and rat liver and the influence of methotrexate on metabolism of folic acid. Journal of Biological Chemistry 249, 5772-5777.

Tamura, T., Shin, Y. S., Williams, M. A. \& StoKSTAD, E. L. R. (1972). Lactobacillus casei response to pteroylpolyglutamates. Analytical Biochemistry 49, 517-52 I.

TAYLOR, R. T. \& WeISSBACH, H. (I973). $N^{5}$-Methyltetrahydrofolate-homocysteine methyltransferases. In The Enzymes, 3rd edn, vol. 9, pp. 121165. Edited by P. D. Boyer. New York: Academic Press.

WAgner, C., Lusty, S. M., Kung, H.-F. \& Rogers, N. L. (1967). Preparation and properties of trimethylsulfonium-tetrahydrofolate methyltransferase. Journal of Biological Chemistry 242, 1287I293.

Whitfield, C. D., Steers, E. J., JR \& Weissbach, H. (I970). Purification and properties of 5-methyltetrahydropteroyltriglutamate - homocysteine transmethylase. Journal of Biological Chemistry 245, 390-401.

WILKINSON, G. M. (1961). Statistical estimations in enzyme kinetics. Biochemical Journal 80, 324-332. 